\title{
WORMS AND THE MAN IN LUCILIUS*
}

\begin{abstract}
This piece explores possible reasons for Lucilius' suggestive reference to worms, emblemate uermiculato, in the famous comment (about speech arranged akin to mosaics) which has survived from Book 2 of the satirist. The fragment can be set metatextually amid other extracts of Lucilius to show the poet's agency and skill, considered as having influenced aspects of its own afterlife (especially in Hor. Sat. 2.4) and appreciated in its historical context as a hit at Publius Mucius Scaevola, who died from phthiriasis.
\end{abstract}

Keywords: Lucilius; worms; mosaic; insects; phthiriasis; satire; invective; Republican lawcourt

One of the most celebrated items of Lucilian satire, the understanding of which I aim to deepen in the following discussion, is the report (on three occasions in Cicero's works, namely, De or. 3.171, Orat. 149-50 and Brut. 274, the last only an indirect paraphrase) of a witticism apparently spoken at a trial during a motion de repetundis brought against Quintus Mucius Scaevola by Albucius in 119 B.C.E. ${ }^{1}$ The passage also appears at Nonius, page 277 Lindsay, its first line is cited by Pliny the Elder ( $H N$ 36.185, who writes there arte pauimenti), and it is paraphrased by Quintilian (Inst. 9.113). The fragment belongs to Lucilius Book 2, our only evidence for the trial of Scaevola (which did not hinder his career, as he was consul in 117 B.C.E., an augur and a highly respected jurist in the 90s). In the Lucilian lines, Albucius' speaking style is being criticized (84-5 Warmington $=84-5$ Marx $):^{2}$

quam lepide lexis conpostae ut tesserulae omnes arte pauimento atque emblemate uermiculato

how charmingly are ses phrases put together-artfully like all the little stones in a paved floor and in a wriggly inlay!

* Translations of Lucilius, Quintilian and Plutarch are taken from the Loeb Classical Library volumes. I would like to thank the anonymous reader for suggestions and prompts to improve, and render more precise, the argument, as well as Joe Howley for alerting me to the Sulla passage, Rosie Wyles for asking the important question, and the editors of $C Q$.

${ }^{1}$ For discussion of this trial, see recently I. Goh, 'Republican satire in the dock: forensic rhetoric in Lucilius', in C. Gray, A. Balbo, R.M.A. Marshall and C.E.W. Steel (edd.), Reading Republican Oratory (Oxford, 2018), 33-48. Cf. also, for example, E.S. Gruen, Roman Politics and the Criminal Courts (Cambridge, MA, 1968), 112-16; R.A. Bauman, Lawyers in Roman Republican Politics: A Study of the Roman Jurists in their Political Setting, 316-82 B.c. (Munich, 1983), 321-9.

${ }^{2}$ For some recent takes on this specific fragment, see S. Koster, 'Lucilius und die Literarkritik', in G. Manuwald (ed.), Der Satiriker Lucilius und seine Zeit (Munich, 2001), 121-31, at 127; S. Butler, The Matter of the Page: Essays in Search of Ancient and Medieval Authors (Madison, 2011), 39-42; D. Mankin, Cicero: De Oratore Book III (Cambridge, 2011), 261-2; W. Fitzgerald, Variety: The Life of a Roman Concept (Chicago, 2016), 71-3. On the reception of the mosaic idea in Late Antiquity, see P. Hardie, Classicism and Christianity in Late Antique Poetry (Berkeley, 2019), 231-2; in the Renaissance, E. MacPhail, 'The mosaic of speech: a classical topos in Renaissance aesthetics', JWI 66 (2003), 249-64.

(C) The Author(s), 2021. Published by Cambridge University Press on behalf of The Classical Association. This is an Open Access article, distributed under the terms of the Creative Commons Attribution licence (https://creative commons.org/licenses/by/4.0/), which permits unrestricted re-use, distribution, and reproduction in any medium, provided the original work is properly cited. 
As for the paraphrases, that in the Brutus seems at first glance to be relatively positive, as Lucilius' words are adapted to observe that in M. Calidius' speech nullum nisi loco positum et tamquam in uermiculato emblemate, ut ait Lucilius, structum uerbum uideres ('you would see no word out of place, as they are arranged as if in a wriggly mosaic, as Lucilius says', Brut. 274), and it is only a little later that Cicero criticizes Calidius' oratory as lacking energy. Quintilian's, in contrast, runs as follows, in the context of a warning against pedantic focussing on trivialities in oratory such as 'measuring out feet' (meaning metrical concerns, as in poetry!): the pedant will have no time for more important things, as relicto rerum pondere ac nitore contempto 'tesserulas', ut ait Lucilius, struet et uermiculate inter se lexis commitet ('he will be forgetting the weightiness of his subject, despising elegance, and, as Lucilius says, making a mosaic, and fitting his words together "in vermiculate work", Inst. 9.113). The contexts of Cicero's Orator and De oratore Book 3 have a similar focus on collocation.

My concern in this discussion is simple: why worms? Most obviously, because mosaics are not always rectilinear. ${ }^{3}$ uermiculatus refers to stone patterns in the opening to Pliny's $H N$ Book 35 (uermiculatisque ad effegies rerum et animalium crustis 'and with mosaic covering to represent things and animals', 35.2: a neat juxtaposition of two animal words) and in the aforementioned quotation of Lucil. 85 Warmington= 85 Marx at Plin. $H N$ 36.185, where mosaics are the subject. ${ }^{4}$ Albucius' rhetoric is thus denigrated as fussy, obtuse and Greek-laden (hence the use of two Greek terms in imitative mockery, $\lambda \dot{\varepsilon} \xi 1 \zeta$ and $\left.\varepsilon^{\prime} \mu \beta \lambda \eta \mu \alpha\right) .{ }^{5}$ The couching of the comparison in the last of these criticisms - namely Greekness-may owe something to the earliest history of the figure of ecphrasis in Roman literature as a response to the appropriation via conquest of Greek artwork. ${ }^{6}$ Moreover, Albucius' intricate and finicky speaking style, the opposite of Scaevola's, ${ }^{7}$ could alternatively be described as the result of excessive attention to prose rhythm, which could make him a representative of an Asianist rhetoric that matches his apparent Epicurean leanings (as opposed to Scaevola's Stoicism). ${ }^{8}$ In

${ }^{3}$ Butler (n. 2), 39 provides an intricate exegesis of the kind of mosaic work here described, in which he alludes to 'the array of wriggling lines' and the later technical term opus uermiculatum; cf. F. Charpin, Lucilius: Satires Tome I, Livres 1-8 (Paris, 1978), 220.

${ }^{4}$ August. De ordine 1.2 also has uermiculato pauimento to mean 'mosaic floor', and uermiculus $=$ emblema uermiculatum at CIL 6.25527.3. Otherwise, uermiculatus is used to denote such things as tree-gum (Plin. HN 13.66) and oysters (Apul. Apol. 35.5).

5 On mockery of philhellenism here, see, for example, K. Hass, Lucilius und der Beginn der Persönlichkeitsdichtung in Rom (Stuttgart, 2007), 197, who gives further bibliography. Simultaneously, the term lepide is trendy Roman 'vocabulary of social performance': L. Roman, Poetic Autonomy in Ancient Rome (Oxford, 2014), 38. A house's adornment with some emblema is a marker of luxury at Varro, Rust. 3.2.4 in the criticism of Appius Claudius, which can be interpreted as hypocritical: L. Kronenberg, Allegories of Farming from Greece to Rome: Philosophical Satire in Xenophon, Varro, and Virgil (Cambridge, 2009), 102-4.

${ }^{6}$ For this, see B. Dufallo, The Captor's Image: Greek Culture in Roman Ecphrasis (Oxford, 2013), especially 1-38. Certainly, the employment of the term arte here is typical of the self-consciousness of ecphrasis.

7 Scaevola was 'gruff and plain-spoken' (B.W. Frier, The Rise of the Roman Jurists: Studies in Cicero's Pro Caecina [Princeton, 1985], 143), as Cicero, whom he taught, characterizes him throughout De or. Book 1 and De Amicitia especially, where he is an interlocutor.

${ }^{8}$ For Albucius as a representative of Asianist bombast, see J.C. Bramble, Persius and the Programmatic Satire (Cambridge, 1974), 24-5. Cicero (Brut. 131) calls Albucius a 'model Epicurean' (perfectus Epicureus) immediately after labelling him 'almost Greek' (paene Graecus). For Epicurean Asianism, see E. Rawson, Roman Culture and Society: Collected Papers (Oxford, 1991), 384. On Epicurean Albucius vs Scaevola the Stoic orator, see Goh (n. 1), 42, 47-8. 
turn, Horace, writing satire in the wake of Lucilius, will censure him by assigning him traits which suggest that he was an Asianist (in the same terms which Cicero had applied to his rival Hortensius, a prominent Asianist, in the Brutus) ${ }^{9}$ We might be alert to a similar move when the 'foodie' Catius is made by Horace, to whose voice he is often assimilated, ${ }^{10}$ to mention mosaics in Sat. 2.4, in the line ten lapides uarios lutulenta radere palma ('To think of your scratching at the multicoloured mosaics with a grimy palm-leaf broom', Sat. 2.4.83). That phrase employs the same word lutulentus with which Horace had previously castigated Lucilius' wordy poetry (Sat. 1.4.11, 1.10.50). Thus here we can read the figure of the broom dirtying the Lucilian mosaics as a reprimand of the older satirist who incompetently sullies his own legacy. ${ }^{11}$ Horace's (or Catius') description of the Lucilian palm as 'scratching' (radere) may recall his earlier vision of his predecessor transported to Horace's own day, where 'he would scratch his head and bite his nails to the quick' (in uersu faciendo | saepe caput scaberet uiuos et roderet unguis, Sat. $1.10 .70-1) .{ }^{12}$

The Lucilian phrase, emblemate uermiculato, has Quintus Mucius Scaevola comparing the speech of his opponent Albucius to both a static and a living thing. The animation inherent in uermiculato serves as an embodiment, which is also mapped by Horace onto his figure in Sat. 2.4, as the broom is both made out of a palm frond and nearly human, if palma = 'palm of the hand'. Another analogue is the technical term colon, the metrical representation of a limb ( $\kappa \hat{\omega} \lambda \mathrm{ov}$ ), as a means of describing speech (in this case, a 'clause' in a 'period') in bodily terms. ${ }^{13}$ The effect of such comparisons is grotesque and enlivening: Albucius' 'wriggly' speech means that he cannot be trusted. ${ }^{14}$ Most pertinently perhaps, the figure of a snake could represent the end of a text or a paragraph, as it has the form of a coronis, the symbol which for ancient readers marked a conclusion. ${ }^{15}$ It is, therefore, possible, though of course unprovable, that the witty

9 So I. Goh, 'An Asianist sensation: Horace on Lucilius as Hortensius', AJPh 139 (2018), 641-74. Here, then, Lucilius' critique of Asianism-cf. Charpin (n. 3), 221—turns into Horace's tendentious criticism of him that he is Asianist.

${ }^{10}$ Cf., for example, C. Classen, 'Horace-a cook?', CQ 28 (1978), 333-48; E. Gowers, The Loaded Table: Representations of Food in Roman Literature (Oxford, 1993), 157.

${ }^{11}$ Gowers (n. 10), 147. Horace already introduced legality into the conversation surrounding Lucilius in Sat. 2.1, though the satiric predecessor is nowhere else mentioned in the book.

12 On Horace's conception of the composition of poetry as an act of belabouring the body, specifically in the case of Lucilius, see J. Farrell, 'Horace's body, Horace's books', in S.J. Heyworth (ed.), Classical Constructions: Papers in Memory of Don Fowler, Classicist and Epicurean (Oxford, 2007), 174-93, at 186-8. Cf. palmisque misellam depuniit me ('he pounded poor me with his palms', 1165 Warmington= 1245 Marx), the one fragment of Lucilius to mention the word palma.

13 See also capita 'heads', another kind of paragraph marker, with the discussion of S. Butler, 'Cicero's capita', in L. Jansen (ed.), The Roman Paratext: Frame, Texts, Readers (Cambridge, 2014), 73-111, especially 81-6 on such sectioning in legal texts before Cicero.

14 These figurations reflect the familiar observations that Roman orators criticized their opponents for their appearance, which bled into defects both moral and in speaking style-see, for example, A. Corbeill, Controlling Laughter: Political Humor in the Late Roman Republic (Princeton, 1996), 14-56 - and that the body of the orator in delivery was a crucial concern in rhetoric: cf., for instance, E. Gunderson, Staging Masculinity: The Rhetoric of Performance in the Roman World (Ann Arbor, 2000), 59-86.

15 See A. Barchiesi, 'Endgames: Ovid's Metamorphoses 15 and Fasti 6', in D.H. Roberts, F.M. Dunn and D. Fowler (edd.), Classical Closure: Reading the End in Greek and Latin Literature (Princeton, 1997), 181-208, at 190-1; cf. Meleager in Anth. Pal. 12.257 .7 for the comparison of

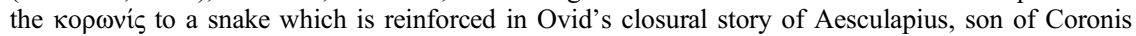
(Coroniden, Ov. Met. 15.624). 
comparison of Albucius' speech to worms (which can, earthworms at least, look like snakes) represents a concluding flourish to Lucilius' record of Quintus Mucius' speech. ${ }^{16}$

Given that the meaning of uermiculatus moves so easily from 'in the form of worms' to 'wriggling', though, we must ask what kinds of worms are meant. Donald Russell, in his Loeb edition of Quintilian, reports the suggestion per litteras of Wesley Trimpi that

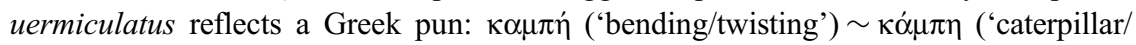
silkworm'). ${ }^{17}$ While the word uermis can denote a 'maggot, or other small creature of sim. appearance' (as the OLD entry states), the diminutive, attested in Varro (Rust. 3.16.17, of the worms that must be cleaned out of beehives) and numerous times in Pliny's Natural History and in Columella, is likely technical or informal, properly used for insect larvae but commonly of the insects themselves. ${ }^{18}$ In this case, both uermes and uermiculi would be larval, and therefore the worms are the individual tessellated tiles, which is to say the distinct words which Albucius uses. ${ }^{19}$ But Varro, in De lingua Latina, reports the observation of a not-well-attested comic playwright about the word scrup $<i>$ peda: Iunentius comicus dicebat a uermiculo piloso qui solet esse in fronde cum multis pedibus ('Iuventius the comic poet said that it comes from a hairy uermiculus which is accustomed to be in the leaves with its many legs', Ling. 7.65). In this case, the uermiculus must be a caterpillar, and there are multiple jokes lurking: on pes (both 'foot' and 'metrical foot') and frons ('leafy branch' and 'stage'). ${ }^{20}$ None the less, a later Lucilian fragment (from Book 7, according to Nonius Marcellus who preserves it), seldom adduced in this context, links worms to the obstruction of hearing: ne auriculum obsidat caries, ne uermiculi qui in Lachmann's reading ('lest a gathering, lest little worms block up your little ear', 298 Warmington $=266$ Marx); these uermiculi must fit, even if metaphorically, inside the ear. ${ }^{21}$ Applying the later fragment to the earlier, it is plausible that an additional charge from the trial is that Albucius' worm-like oratory obstructs the listener's

${ }^{16}$ In the following sentence, as Crassus introduces his other quotation from the trial in De or. 3.171, cum could mean 'although': quae cum dixisset in Albucium inludens, ne a me quidem abstinuit 'Although he had said these things in jest against Albucius, he did not even refrain from toying with me'. That said, my position that the worm witticism represents a mark of closure allows for a less extreme conclusion, in that it could have been placed at the end of a section of the speech.

17 D. Russell, Quintilian: The Orator's Education (Cambridge, MA, 2001), 4.224, echoed by Butler (n. 2), 121.

${ }^{18} \mathrm{I}$ owe this formulation to the anonymous reader.

19 So concludes F. Marx, C. Lucilii carminum reliquiae (Leipzig, 1904-5), 2.39: 'individual tiles (tessellae singulae) may be very similar to worms (uermiculis simillimae)'. That said, he does then attribute uermiculatum to the whole mosaic work to justify Quintilian's use (Inst. 9.113, cited above) of the adverb uermiculate. Cf. Cic. Orat. 150, after the Lucilius quotation: haec tam minuta constructio appareat '[lest] this construction appear so trivial/miniature'.

${ }^{20}$ I follow D. Spencer, Language and Authority in De lingua Latina: Varro's Guide to Being Roman (Madison, WI, 2019), 82, who notes these puns.

${ }^{21}$ Regarding diminutives, of which there are two in this particular fragment: I. Mariotti, Studi Luciliani (Florence, 1960), 124 mentions uermiculato alongside tesserulae ( 84 Warmington $=84$ Marx) and comments mostly on the latter as hypocoristic, creating an 'expressive nuance' ('sfumatura espressiva') that links the preciousness and refinement of mosaics to Albucius' speech; R.F. Thomas, 'Grist to the mill: the literary uses of the quotidian in Horace, Satire 1.5', in E. Dickey and A. Chahoud (edd.), Colloquial and Literary Latin (Cambridge, 2010), 255-65, at 258 similarly labels auriculam at Hor. Sat. 1.9.77 as hypocoristic (attenuating Virgil's aurem, Ecl. 6.3). See, however, J.N. Adams, Pelagonius and Latin Veterinary Terminology in the Roman Empire (Leiden, 1995), 544 n. $322,550-1$ on auricula as referring to the ear lobe or (more usually) to the auditory canal, i.e. a part of the whole, and then to the ear itself, either as displaying a 'marked characteristic' or, technically, for the ear of an animal. It is unknown whether Lucilius' auriculum is the ear of a human or of an other animal. 
hearing and impedes their comprehension (despite the style's ostensible mosaic-like charms).

This conclusion depends on a slippage from sight (of a mosaic) to sound (of speaking). ${ }^{22}$ The former, in physical form, is ostensibly more permanent than the latter-a theme implicit in the recording of the events of the trial. ${ }^{23}$ Such an assertion of the satirist's role in shaping the record of events reflects the possibility that small wriggly insects (lice, now, as well as worms) have something to do with Lucilius' poetic individuality. There are statements elsewhere in the Lucilian fragments which portray the satiric 'I' in a proud position, owning up to lice: mihi quidem non persuadetur, pulices mutem meos ('indeed, I am not persuaded to (ex)change my lice', 647 Warmington $=675$ Marx $).{ }^{24}$ Similar are lines 904-5 Warmington $=882-3$ Marx: hic ubi me uidet $\mid$ subblanditur, <sub>palpatur, caput scabit, pedes legit ('when this fellow sees me, he caresses me gently, pats me lightly, scratches my head, gathers the lice'): caput scabit in this fragment is perhaps picked up by Horace in his caput scaberet of the modern-day Lucilius (Sat. 1.10.71, quoted above). ${ }^{25}$ But alongside this possible function that these insects could serve as a marker of poetic independence, it is pertinent, in light of the fact that Lucilius' satire provides a more permanent record of the trial that would not decay, that uermiculi could also be markers of decay. ${ }^{26}$ This was a staple of ancient thought, despite the absence of a germ theory of disease, ${ }^{27}$ even in Roman Republican times, as can be seen from the identification of phthiriasis, the disease whose victims are consumed by worms, as a feature of the ignominious death of Sulla. ${ }^{28}$ That event is most strikingly reported by Plutarch, who goes on to write about other historical casualties of worms (Sull. 36.3):29

${ }^{22}$ Butler (n. 2), 42 has interesting comments on this, with regard to Cicero's alternately negative and positive valuations of the mosaic image.

${ }^{23}$ Goh (n. 1), 35-40 explores the question of accuracy in court reporting as it applies to Lucilius Book 2.

${ }^{24}$ See K.F. Smith, 'Mutare pulices', AJPh 22 (1901), 44-50; B. Zucchelli, L'indipendenza di Lucilio (Parma, 1979), 84 n. 7; G. Garbugino, 'Tre cruces luciliani', Studi Noniani 9 (1984), 11136 , at $120-2$.

${ }^{25}$ See C. Damon, The Mask of the Parasite: A Pathology of Roman Patronage (Ann Arbor, 1997), 263. One of the words for 'louse', pedis, is derived from 'foot', cuing up a possible metrical joke like that at Varro, Ling. 7.65 quoted above; lice, like hexameters (Lucilius' bequest to later satire), have six feet (and Aristotle knew that insects have six, Part. an. 4.683b4); cf. Hor. Sat. 1.10.59, with the possibility there of further jokes: E. Gowers, Horace: Satires Book I (Cambridge, 2012), 330.

${ }^{26}$ Cf. Lucr. 2.899, 3.728; Plin. HN 10.186. The base form uermis could have the same force or implication as the diminutive: cf. Cato, Agr. 162.3 (on preserving hams); Varro, Rust. 1.57.2; Lucr. 2.871, 2.928, 3.719.

27 As stressed by I.C. Beavis, Insects and Other Invertebrates in Classical Antiquity (Exeter, 1988), 116-18, though see Varro, Rust. 1.12.2 on minute airborne creatures in swampland.

${ }^{28}$ See now the full discussion of B. Walters, 'Sulla's phthiriasis and the Republican body politic', Mnemosyne 72 (2019), 949-71.

29 A.J. Keaveney and J.A. Madden, 'Phthiriasis and its victims', SO 62 (1982), 87-99, at 90 give a brisk history of death by worms (or lice) and dismiss moral implications as imported via the

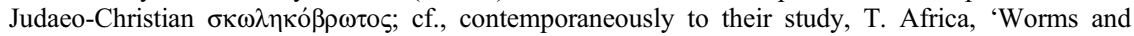
the death of kings: a cautionary note on disease and history', ClAnt 1 (1982), 1-17. For more on phthiriasis, see M. Davies and J. Kathirithamby, Greek Insects (Oxford, 1986), 173-6; Beavis (n. 27), 112-20; J. Bondeson, A Cabinet of Medical Curiosities (New York, 1997), 51-71; F.A. Bahmer and A. Eckert, 'Phthiriasis, die geheimnisvolle Läusekrankheit der Antike. Fakt oder Fiktion?', Der Hautarzt 66 (2015), 143-8. 
But it was of no use; for the change gained upon him [sc. Sulla] rapidly, and the swarm of vermin defied all purification. We are told that in very ancient times Acastus the son of Pelias was thus eaten of worms and died, and in later times Alcman the lyric poet, Pherecydes the theologian, Callisthenes of Olynthus, who was kept closely imprisoned, as also Mucius the jurist

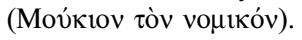

Who is 'Mucius the jurist'? He is 'generally assumed' to be Publius Mucius Scaevola, ${ }^{30}$ consul in 133 and pontifex maximus from 130, who was cousin to Quintus Mucius Scaevola Augur defending in the Lucilian case where the latter (presumably) utters the 'worm-like emblem' lines. All we know about Publius' death is that his son, also a jurist later on (who cannot be the Mucius in mind because he was assassinated), was co-opted as pontifex as a successor to his father in about 115; as this must have occurred shortly after the father's death, 115 is the likely date of that event. ${ }^{31}$ One other fact that may lead to an identification of Publius as the victim of phthiriasis is that he is particularly associated (admittedly, later on by Cicero) with the strictures of the 'pontifical law' (ius pontificale) on how to deal with unusual situations relating to burial ritual. We learn from Cicero that Publius had declared that in the case of death at sea the family of the deceased was undefiled, and had prescribed the sacrifice of a sow and a three-day holiday if the death took place on a ship rather than in the water (Leg. 2.57); Cicero has just been describing how the ius pontificale prescribed earth to be thrown onto the bones. ${ }^{32}$ Publius' laying down of the law on religious norms did not avail him any when he died, consumed by worms.

We do not know when Lucilius wrote the satire (apart from, obviously, after the trial of 119 в.C.E.), so it is possible that it post-dates Publius' death also. If that is the case, Lucilius may anachronistically be putting words into Quintus' mouth which have extra resonance in the light of his relative's death. That is to say: when Lucilius' satire has Quintus talking about worms, the satire's audience recalls Publius' more recent demise owing to worms and contrasts Quintus' escape from Albucius' worms. It is noteworthy that the other line which Lucius Licinius Crassus, the son-in-law of Quintus and the reporter of proceedings in the account of Cicero's De oratore, ascribes to his father-in-law in the trial features another family relation, in this case Crassus himself: Crassum habeo generum, ne rhetoricoterus tu sis ('I've Crassus for a son-in-law, lest you be too much l'orateur', 86 Warmington $=86$ Marx, transl. Warmington). ${ }^{33}$ In this line as in the worm fragment, I suggest, Quintus is made to claim expertise in an

${ }^{30}$ The phrase is that of Africa (n. 29), 3. See already H.A. Holden, Plutarch: Life of Lucius Cornelius Sulla (Cambridge, 1886), 190 (with no explanation), even if, as Keaveney and Madden (n. 29), 99 state, there are many contenders.

${ }^{31}$ For this, see J. Rüpke (transl. D.M.B. Richardson), Fasti Sacerdotum: A Prosopography of Pagan, Jewish, and Christian Religious Officials in the City of Rome, 300 B.C. to A.D. 499 (Oxford, 2008), 804-5; cf. Bauman (n. 1), 298.

32 See J. Rüpke (transl. D.M.B. Richardson), Religious Deviance in the Roman World: Superstition or Individuality? (Cambridge, 2016), 13-14. In an earlier chapter, Cicero has noted that Publius and his son Quintus Mucius Scaevola Pontifex 'added civil law to pontifical law', thus 'in a certain sense obviating the pontifical law' (Leg. 2.52). Just as Lucilius was the inventor of Roman verse satire, Publius, along with his son, is therefore an innovator: cf., for example, J. Harries, Cicero and the Jurists: From Citizens' Law to the Lawful State (London, 2006), 13-14 and passim. He first compiled the Annales Maximi too: Bauman (n. 1), 290-7.

${ }^{33}$ Goh (n. 1), 41-2 reads the Greek terminology in this instance as implying that certain kinds of oratory are unappealing, in an artful reinforcement of the suspect or grotesque overtones of the worm reference with its own Greek terminology, as outlined above. 
awkward situation (oratorical over-exuberance, worm-like structure) via a family member. ${ }^{34}$

So, does the line about worms serve to undercut the gravity of a formal occasion, a trial on a serious charge, with a literally earthy image ${ }^{35}$ And is Lucilius advertising his impartiality, in that neither side in the case is favoured by the questionably appropriate and indeed anachronistic witticism? ${ }^{36}$ I would make two claims. My first claim, building on my earlier argument about Lucilius' provision of a more permanent record of the trial, is that the satirist's intervention serves to point out his agency in the moulding of our memories of the Scaevola-Albucius trial, in that Lucilius records the worm witticism for posterity, and it gains additional force from events subsequent to the trial. And my second, more prosaic claim is that Lucilius had a good reason to take a sideswipe at Publius Mucius Scaevola. Another famous Lucilian testimonium is offered by the anonymous author of the Rhetorica ad Herennium (Rhet. Her. 2.19):

C. Caelius iudex absoluit iniuriarum eum, qui Lucilium poetam in scaena nominatim laeserat: P. Mucius eum, qui L. Accium poetam nominauerat, condemnauit.

Gaius Caelius, as judge, acquitted of the charge of injury the man who had by name attacked the poet Lucilius on the stage, while Publius Mucius condemned the man who had specifically named the poet Lucius Accius.

If both of these episodes happened before Lucilius wrote Book 2, which is likely in the Accius case, dated to 135 or $134,{ }^{37}$ and if we believe that Caelius could have been L. Caelius Antipater (who died in 120), ${ }^{38}$ then it is possible that Publius Mucius could be referred to via the worm image in Lucilius' account of the trial of Publius' cousin. ${ }^{39}$ On this interpretation, even one celebrated detail of Lucilius' record of the trial of Quintus provides a last point-scoring opportunity on an oblique adversary (in so far as Publius was not the judge in Lucilius' case) who is now dead. ${ }^{40}$

${ }^{34}$ Cf. E. Gowers, 'Knight's moves: the son-in-law in Cicero and Tacitus', ClAnt 38 (2019), 2-35, at 12 on the appropriateness of such 'homosocial banter'.

35 This technique could be seen as typically Lucilian: cf. the fragments involving 'snake-like gangrene' (herpestica ... gangraena, 52 Warmington = 53 Marx) and 'jaundice' (icterus morbus, after Scaliger, 37 Warmington = 44 Marx), from the trial of Lupus in Lucilius Book 1; for some discussion, see I. Goh, 'Scepticism at the birth of satire: Carneades in Lucilius' Concilium Deorum', CQ 68 (2018), 128-42, at 136-7.

${ }^{36}$ E. Gruen, Culture and National Identity in Republican Rome (Ithaca, 1992), 301 is right to observe that Lucilius is an equal-opportunity purveyor of invective; this trial is the subject at 2901. Even though Quintus Mucius Scaevola Augur was the son-in-law of Laelius, Lucilius' friend, this does not immunize him, nor can we properly establish how close Publius Mucius was to his cousin the Augur; cf. A.H. Bernstein, 'Prosopography and the career of Publius Mucius Scaevola', CPh 67 (1972), 42-6, at 42. See Cic. De or. 1.72, where Lucilius is subiratus ('not very friendly') to Quintus Augur.

${ }^{37}$ So Bauman (n. 1), 244.

${ }^{38}$ For this identification, see C. Cichorius, Untersuchungen zu Lucilius (Berlin, 1908), 60, who explains away the different praenomina by common scribal error; W. Barr, 'Lucilius and Accius', RhM 108 (1965), 101-3 extends the argument to Lucilius Book 2. For discussion of Lucilius' perhaps surprising lawsuit, see, for example, R.A. Lafleur, 'Horace and onomasti komodein: the law of satire', ANRW 2.3.13 (1981), 1790-826, at 1820-1.

39 Therefore, this argument goes further than the conservative conclusion given by Goh (n. 1), 43, namely, that Publius is involved but not specifically attacked. Note that G. Manuwald, Roman Republican Theatre (Cambridge, 2011), 53 dates both lawsuits much later, to around 115 in the run-up to that year's censorial ban of the performing arts from Rome.

${ }^{40}$ While Bauman (n. 1), 243 n. 128 thinks Barr (n. 38) lacks merit, as Lucilius' animus would have been against Caelius, not Publius Mucius, surely it is likely that Lucilius would have contrasted 
There are, of course, lots of 'ifs' here. None the less, I hope at least to have shown that Lucilius' captivating and memorable worms can, despite being slippery, be pinned down to an extent as proof of satiric sophistication, since we seem to observe some trace of the satirist's hand in massaging the record of Scaevola's worm witticism. We have also more precisely delineated the nature and meaning of these more-than-mosaic worms.

Swansea University

IAN GOH

i.k.1.goh@swansea.ac.uk

Accius' comparative success with the lenient treatment doled out to his attacker and would have blamed not just the judge in his case but also that in Accius'. Cichorius (n. 38) 57, 149 n. 1 already identified Publius as a Lucilian target, for different (even more speculative, to do with the Gracchan catastrophe) reasons. It is agreed by many scholars that Lucilius criticized Accius (compare the comment on Accius' statue, 844 Warmington $=794$ Marx, and Hor. Sat. 1.10.53, nil comis tragici mutat Lucilius Acci? 'is there nothing of the tragedian Accius that polite Lucilius alters?', with the testimony of Porphyrio ad loc. on Lucilius Book 3), although see Manuwald (n. 39), 217, who suggests that the criticism was merely about the unrealistic elements in Accius' drama. 